\title{
New developments in recirculating aquaculture systems in Europe: A perspective on environmental sustainability
}

\author{
C.I.M. Martins ${ }^{a, b}{ }^{,}{ }^{*}$, E.H. Eding ${ }^{a}$, M.C.J. Verdegem ${ }^{a}$, L.T.N. Heinsbroek ${ }^{a}$, O. Schneider ${ }^{c}$, J.P. \\ Blancheton $^{\mathrm{d}}$, E. Roque d'Orbcastel ${ }^{\mathrm{a}}$ and J.A.J. Verreth ${ }^{\mathrm{a}}$
}

\author{
${ }^{a}$ Aquaculture and Fisheries Group, Wageningen University, P.O. Box 338, $6700 \mathrm{AH}$, Wageningen, \\ The Netherlands \\ ${ }^{b}$ CCMAR - Centro de Ciências do Mar, Universidade do Algarve, Campus de Gambelas, P-8005-139, \\ Faro, Portugal \\ ${ }^{c}$ IMARES, Korringaweg 5, 4401 NT Yerseke, The Netherlands \\ d IFREMER, Station d'Aquaculture Expérimentale, Laboratoire de Recherche Piscicole de \\ Méditerranée, Chemin de Maguelone, 34250 Palavas-les-Flots, France \\ *: Corresponding author : C.I.M. Martins, Tel.: +351 289 800900x7167; fax: +351 289 800051, email \\ address : cimartins@ualg.pt
}

\begin{abstract}
:
The dual objective of sustainable aquaculture, i.e., to produce food while sustaining natural resources is achieved only when production systems with a minimum ecological impact are used. Recirculating aquaculture systems (RASs) provide opportunities to reduce water usage and to improve waste management and nutrient recycling. RAS makes intensive fish production compatible with environmental sustainability. This review aims to summarize the most recent developments within RAS that have contributed to the environmental sustainability of the European aquaculture sector. The review first shows the ongoing expansion of RAS production by species and country in Europe. Life cycle analysis showed that feed, fish production and waste and energy are the principal components explaining the ecological impact of RAS. Ongoing developments in RAS show two trends focusing on: (1) technical improvements within the recirculation loop and (2) recycling of nutrients through integrated farming. Both trends contributed to improvements in the environmental sustainability of RAS. Developments within the recirculation loop that are reviewed are the introduction of denitrification reactors, sludge thickening technologies and the use of ozone. New approached towards integrated systems include the incorporation of wetlands and algal controlled systems in RAS. Finally, the review identifies the key research priorities that will contribute to the future reduction of the ecological impact of RAS. Possible future breakthroughs in the fields of waste production and removal might further enhance the sustainabilty of fish production in RAS.
\end{abstract}

Keywords: Intensive systems; Ecological impact; Waste; Water re-use; Denitrification

\begin{abstract}
Abbreviations: RASs, recirculating aquaculture systems; LCA, life cycle analysis; ISO, International Organization for Standardization; GWP, global warming potential; NPPU, net primary product use; NPP, net primary product; EP, eutrophication potential; $E_{u}$, energy use; AP, acidification potential; FTS, flow-through systems; FCR, feed conversion ratio; IMTA, integrated multi-trophic aquaculture; USBR, upflow sludge blanket reactor; HRAP, high-rate algal ponds; PAS, partitioned aquaculture systems; Anammox, anaerobic ammonium-oxidation; TOD, total oxygen demand; COD, chemical oxygen demand; BOD, biological oxygen demand; TSS, total suspended solids; TDS, total dissolved solids; TN, total nitrogen; TAN, total ammonia nitrogen; TP, total phosphorus; OC, organic carbon
\end{abstract}




\section{Introduction}

Aquaculture has been on the frontline of public concerns regarding sustainability. Different issues are raised, such as the use of fish meal and oil as feed ingredients (Naylor et al., 2000), escapees of farmed fish from sea cages into the wild and the discharge of waste into the environment (Buschmann et al., 2006). Recirculation aquaculture systems (RAS) are systems in which water is (partially) reused after undergoing treatment (Rosenthal et al., 1986). Each treatment step reduces the system water exchange to the needs of the next limiting waste component. Based on system water exchange it is possible to distinguish between flow through $\left(>50 \mathrm{~m}^{3} / \mathrm{kg}\right.$ feed), reuse $\left(1-50 \mathrm{~m}^{3} / \mathrm{kg}\right.$ feed), conventional recirculation (0.1-1 $\mathrm{m}^{3} / \mathrm{kg}$ feed) and 'next generation' or 'innovative' RAS $\left(<0.1 \mathrm{~m}^{3} / \mathrm{kg}\right.$ feed). RAS have been developed to respond to the increasing environmental restrictions in countries with limited access to land and water. Furthermore, the new EU water management directive (Directive 2000/60/EC 23rd Oct 2000) calls for sound environmental friendly aquaculture production systems. RAS offer advantages in terms of reduced water consumption (Verdegem et al., 2006), improved opportunities for waste management and nutrient recycling (Piedrahita, 2003) and for a better hygiene and disease management (e.g Summerfelt et al., 2009; Tal et al., 2009), biological pollution control (no escapees, Zohar et al., 2005), and reduction of visual impact of the farm. These systems are sometimes referred to as 'indoor' or 'urban' aquaculture reflecting its independency of surface water to produce aquatic organisms. In addition, the application of RAS technology enables the production of a diverse range of (also exotic) seafood products in close proximity to markets (Masser et al., 1999; Schneider et al. 2010), thereby reducing carbon dioxide $\left(\mathrm{CO}_{2}\right)$ emissions associated with food transport and the negative trade deficits related to EU imports of seafood.

Despite its environmentally friendly characteristics and the increasing number of European countries applying RAS technology, its contribution to production is still small compared to (sea) cages, flow-through systems or ponds. The slow adoption of RAS technology is in part due to the high initial capital investments required by RAS (Schneider et al., 2006). High stocking densities and productions are required to be able to cover investment costs. As a consequence welfare concerns may arise (Martins et al., 2005). However, due to the possibility to maintain a constant water quality, RAS may also contribute to an improved welfare (Roque d'Orbcastel et al., 2009a).

Managing disease outbreaks pose specific challenges in RAS in which a healthy microbial community contributes to water purification and water quality. Minerals, drug residues, hazardous feed compounds and metabolites may accumulate in the system (Martins et al. $2009 a, b)$ and affect the health, quality and safety of the farmed animal. How these different factors interact and influence the fish and the various purification reactors is still poorly understood. Furthermore, RAS historically developed producing freshwater fish species that are rather tolerant to poor water quality. The expansion of RAS being used for the production of marine and brackish water species often focuses on hatchery operations which pose extra requirements on water quality and require further innovations in RAS technology.

Taken together, these examples reflect environmental, economic and social challenges to the sustainability of RAS. Considering these challenges, an European effort was made (e.g. CONSENSUS, www.euraquaculture.infol, SUSTAINAQUA, www.sustainaqua.com; SUSTAINAQ www.sustainaq.net; AQUAETREAT www.aquaetreat.org) to identify the most relevant sustainability issues for RAS, to quantify sustainability in RAS and to develop new technologies to improve sustainability of RAS. This review summarizes recent developments that contributed to the environmental sustainability of the aquaculture production in RAS in Europe. These developments are either technology (e.g. incorporation of new water treatment units that reduce water exchange rates and reduce/concentrate waste) or ecology driven (e.g. biological re-utilisation of wastes). 


\section{RAS within European Aquaculture- Representative species, countries and production}

Data on RAS production is generally difficult to evaluate, as there is no compiled dataset available for this type of production system in Europe. For the purpose of this review an update of the previously published production data in RAS (Martins et al., 2005) was performed. Nevertheless, both grow-out and fingerling production data are still incomplete and many national organizations and stakeholders are not able to provide conclusive data. Tables 1 and 2 summarize the updated production data by species and country. RAS technology is mainly established in The Netherlands and Denmark with raising interest in other European countries for both hatchery and grow-out production. The Dutch RAS are typically indoor, nearly closed systems (water refreshment rate ranges between $30 \mathrm{~L} / \mathrm{kg}$ feed/day and 300L/kg feed/day, Martins et al., 2009b) for freshwater production of African catfish and eel. The Danish model trout farms are outdoor, semi-closed systems for trout ongrowing using $3900 \mathrm{~L} / \mathrm{kg}$ feed or $1 / 13$ of traditional trout farming (Jokumsen et al., 2009). In France a trout RAS, designed after the Danish model trout farms was operated at a water refreshment rate of $9000 \mathrm{~L} / \mathrm{Kg}$ feed/day (Roque d'Orbcastel et al., 2009b).

Since their introduction in the late 80's RAS production increased significantly in volume and species diversity (Rosenthal, 1980; Verreth and Eding, 1993; Martins et al., 2005). Today more than 10 species are produced in RAS (African catfish, eel and trout as major freshwater species and turbot, seabass and sole as major marine species). Recently, new facilities were established in the UK (sea bass), France (salmon) and Germany (different marine species). Two major new developments in Europe at the moment are the increasing production of trout in outdoor RAS in Denmark and the decreasing production of African catfish and European eel in indoor RAS in The Netherlands. In Denmark, government pressure and rules limiting feeding stimulated the shift towards outdoor RAS (Pedersen et al., 2008). Competition with Pangasius imports for African catfish and increasing societal pressure to reduce consumption of endangered eel constraints the demand (van Duijn et al., 2010). At the moment there is serious doubt if the Dutch production for these two species will be able to recover to former levels or stay at this lower production volume.

Available data suggests that hatchery production is shifting towards RAS technology. An example is the production of Atlantic salmon smolts in the Faeroe Islands where a complete shifting from flow-through farms into RAS took place after 2000 (Bergheim et al., 2008, 2009). Joensen (2008) reported an increase of smolt size from 50-70 g from flow-through farms to $140-170 \mathrm{~g}$ in RAS. In Norway a production of 85 million smolts in RAS is foreseen (Del campo et al., 2010). Future water shortage, large season variation in water temperature and low inlet water quality (including aluminium concentrations) are the main factors driving the shift of smolts production from flow-through to RAS in Norway (Kristensen et al., 2009). In addition, Terjesen et al. (2008) suggested an increased smolt quality (growth and survival after sea transfer) in RAS- cultured smolts.

\section{New developments in RAS leading to environmental sustainability}

\subsection{Sustainability assessment: Is RAS environmentally sustainable?}

Life Cycle Analysis (LCA) is an International standardized method (ISO, 2006) designed to assess the global and regional impacts of a product or a process on the environment. It implies impact assessment of all actions and means required to produce, distribute and use a product: raw material use, infrastructures, energy, processing and all the emissions (in air, water and soil) linked to the product or process. The LCA can be divided into four steps: 
definition of the system limits, data inventory, data translation into environmental impact indicators and results analysis and interpretation.

LCA has been used to study the environmental sustainability of aquaculture systems (Seppala et al., 2001; Papatryphon et al., 2004a,b; Aubin et al., 2006, 2009; Ayer and Tyedmers, 2009; Ellingsen et al, 2009; Roque d'Orbcastel et al., 2009c). Environmental impact indicators are defined both at the global and at the regional levels. Indicators usually used for fish farms are, at the global level, the Global Warming Potential (GWP in $\mathrm{kg} \mathrm{CO}$ eq.) which measures the impact of gaseous emissions as $\mathrm{CO}_{2}$, methane $\left(\mathrm{CH}_{4}\right)$, nitrous oxide $\left(\mathrm{N}_{2} \mathrm{O}\right)$ on global greenhouse effect, the Energy use (E in $\left.\mathrm{MJ}\right)$ which corresponds to all energy sources (coal, gas, uranium, etc) used in the system, the surface use $\left(\mathrm{m}^{2}\right)$ which represents the land surface used in the system life cycle and sometimes the Net Primary Product Use (NPPU in kg of carbon (C)) which represents the use of net primary product (NPP) as a biotic resource. At the regional level, the Eutrophication Potential (EP in $\mathrm{kg} \mathrm{PO}_{4}{ }^{3-}$ equivalent or $\mathrm{PO}_{4}{ }^{3-} \mathrm{eq}$ ) measures the environmental impact of macronutrients such as nitrogen and phosphorus on ecosystems and the Acidification Potential (AP in $\mathrm{kg} \mathrm{SO}_{2}{ }^{-}$equivalent or $\mathrm{SO}_{2}{ }^{-}$ eq) evaluates the impact of acidifying pollutants (sulphur dioxide, $\mathrm{SO}_{2}$; ammonia, $\mathrm{NH}_{3}$; nitrite, $\mathrm{NO}_{2}$; nitrogen oxides, $\mathrm{NO}_{x}$ ) on ecosystems.

Using LCA, Roque d'Orbcastel et al. (2009c) compared the environmental impacts of 3 systems of which 2 RAS and one flow-through system (FTS) (Fig. 1).

Contribution analysis showed that in FTS and RAS, Feed had the strongest impact on all indicators, Fish production and wastes explained 50 to $60 \%$ of the system 's eutrophication potential and Energy use was mainly due to Electricity consumption to operate the systems ( $2 / 3$ in RAS and $1 / 2$ in FTS) and feed (1/3 in RAS and $1 / 2$ in FTS). Other contribution categories explained less than $6.5 \%$ of the global environmental impact $(4 \%$ for equipments, less than $2 \%$ for infrastructures and less than $0.2 \%$ for chemicals).

\subsubsection{Feed}

First solution to reduce the environmental impacts of aquaculture systems consists in minimizing the Feed Conversion Ratio (FCR): a 30\% reduction of FCR in a trout farm resulted in a reduction of almost $20 \%$ of the global environmental impact, excluding energy use (Roque d'Orbcastel et al., 2009c). RAS provides optimal environmental conditions all year round (total ammonia nitrogen and dissolved $\mathrm{CO}_{2}$ concentrations were lower in the RAS than in the FTS), contributes to fish welfare and minimizes the FCR, hence improving feed efficiency (Losordo 1998a; Losordo 1998b; Roque d'Orbcastel et al., 2009a). Feed impact on the environment may also be reduced by choosing local feed ingredients and ingredients from a low trophic level (e.g. proteins and lipids from phytoplankton rather than from fish), provided feed digestibility does not decrease.

\subsubsection{Fish Production and Waste}

High flow rates of low concentrated effluents are the main obstacle to the economic treatment of waste water from FTS. By comparison, the flow rate of RAS waste water is 10 to 100 times lower and 10 to 100 times more concentrated (Blancheton et al., 2007), which allows for easier and more cost effective treatment.

Pedersen et al. (2008) also showed a reduction on the environmental impact from converting flow through trout farms into RAS including waste management. In RAS, removal efficiencies were between $85-98 \%$ for organic matter and suspended solids and between $65-96 \%$ for phosphorous.

Different combinations of waste treatment systems were studied at marine and freshwater fish farms operated in flow through or in recirculation, through an EU project (www.aquaEtreat.org). The general treatment scheme implemented at all the farms included a series of water treatment units at different locations in the farms and settling of backwash 
water, to obtain (1) sludge with more than $15 \%$ of dry matter, which may be valorised as fertilizer directly or after composting, (2) supernatant water from the backwash water tank, that can be treated through constructed wetlands alleviating the load of suspended solids and the biological oxygen demand (Roque d'Orbcastel, 2008) and (3) filtered water (recirculating water low in suspended solida) which returns to the fish tanks. Most of the time, filtered water from flow through systems is not treated. However, according to the fish biomass, water flow rate and legislation, total ammonia nitrogen (TAN) concentration can reach levels requiring a treatment. It is a true economic challenge as the water flow rate to be treated is high (50 to $100 \mathrm{~m}^{3} / \mathrm{kg}$ fish produced) while the nutrient concentrations in the effluent are low (e.g. around $1 \mathrm{mg}$ TAN/L). Concerning marine RAS, filtered water may be treated in a High Rate Algal Pond (HRAP) (see latter section 3.3) and reused in RAS without inducing sea bass mortality or decreasing growth and reducing the water consumption to less that $1 \mathrm{~m}^{3}$ of water per $\mathrm{kg}$ fish produced (Metaxa et al., 2006). Improved waste treatment and linkage with cultures of extractive species may further alleviate the environmental impact from fish farms. Integrated Multi-Trophic Aquaculture (IMTA) where the by-products (wastes) from one species become inputs for other co-cultured species (Hussenot, 2006) may be the solution.

\subsubsection{Energy}

Roque d'Orbcastel et al. (2009c) calculated that energy use through LCA is 1.4-1.8 higher in RAS $(63,202 \mathrm{MJ}$ per ton of fish or $16 \mathrm{kWh}$ per $\mathrm{kg}$ fish) than in flow-through systems. Energy use reduction in RAS is possible by improving the system design and management of airlifts and biofilters (Roque d'Orbcastel et al., 2009c) or the incorporation of denitrification in the recycling loop (Eding et al., 2009). A reduction of transport of feed ingredients in fish feeds will further lower energy consumption.

Table 3 shows that the energy consumption per $\mathrm{kg}$ of trout or sea bass produced in FTS and RAS is comparable to the amount needed to capture $1 \mathrm{~kg}$ of cod at sea (5 to $21 \mathrm{~kW} / \mathrm{kg}$ ). Recent RAS designs minimize height differences between RAS compartments and also pumps became more efficient or replaced by air lifts. This resulted already in a $50 \%$ reduction in energy use, a trend which continues, considering further improvements such as completely low head RAS with only few centimetres of height differences or raceway systems that use and treat water alongside cascades.

\subsection{Developments in the recirculation loop}

Producing fish in conventional RAS, in which a large volume of water is refreshed and a limited number of water treatments units are used (essentially mechanical waste removal and biofiltration) has a smaller environmental impact than flow through systems. Recent innovations such as denitrification reactors, sludge thickening technologies and ozone treatments led to a further decrease in water use, waste discharge and energy use in RAS. In addition, the discharged waste is more concentrated, facilitating waste (re-)use options as fertilizer or in integrated, eventually completely closed, systems (reviewed in section 3.3). Combined, these developments certainly improve the environmental sustainability of RAS.

\subsubsection{Denitrification reactors}

Conventional RAS are operated at variable water refreshment rates $(0.1-1 \mathrm{~m} 3 / \mathrm{kg}$ feed). For instance in RAS producing European eel, refreshment rates are about 200-300 L per kg feed (Eding and Kamstra, 2002; Martins et al., 2009b). In these systems, solids are removed by 
sedimentation or sieving, oxygen is added by aeration or oxygenation, carbon dioxide is removed by degassing and ammonia is mostly converted into nitrate $\left(\mathrm{NO}_{3}\right)$ through nitrification in aerobic biological filters. In a conventional RAS the maximum allowed concentration of $\mathrm{NO}_{3}$ steers the external water exchange rate (e.g Schuster and Stelz, 1998). High nitrate concentrations can be counteracted by denitrification (Rijn and Rivera, 1990; Barak, 1998; Rijn and Barak, 1998; van Rijn et al., 2006). Denitrification reactors applied to RAS have different designs (see review from van Rijn et al., 2006). One of the designs that have been used successfully in pilot scale recirculating systems is the upflow sludge blanket denitrification reactor (USB-denitrification reactor, Figure 2). This reactor is a cylindric anoxic (no free dissolved oxygen; $\mathrm{NO}_{x}$ present) reactor fed with dissolved and particulate faecal organic waste, bacterial flocs and inorganic compounds trapped by the solids removal unit. The waste flow enters the reactor at the bottom centre. The up flow velocity in the reactor is designed to be smaller than the settling velocity of the major fraction of the particulate waste in order to create a sludge bed at the bottom. In the sludge bed the faecal particulate waste is digested by the denitrifying bacteria and results in: (1) the production of bacterial biomass, (2) reduction of $\mathrm{NO}_{3}$ into nitrogen gas $\left(\mathrm{N}_{2}\right),(3) \mathrm{CO}_{2}$ release, and (4) alkalinity and (5) heat production. The particulate waste in the sludge bed serves also as substrate for the denitrifying bacteria. Pre-settled water leaves the reactor through a V-shaped dented overflow at the top section of the reactor.

As an example, since 2005, a denitrification reactor using internal carbon source, was integrated into a conventional RAS (Figure 2) in The Netherlands. In a $600 \mathrm{MT} / \mathrm{year}$ Nile tilapia Oreochromis niloticus RAS farm the water exchange rate was as low as $30 \mathrm{~L} / \mathrm{kg}$ feed, corresponding to $99 \%$ recirculation (Martins et al., 2009b). Such an extreme low water exchange rate became possible by incorporating a denitrification reactor in RAS to convert $\mathrm{NO}_{3}$ into nitrogen gas $\left(\mathrm{N}_{2}\right)$. Organic matter (either of external origin, i.e. methanol, but preferably of internal origin, i.e. the uneaten feed and faeces from the solids removal) is oxidized by reducing $\mathrm{NO}_{3}$. Compared to a conventional RAS, this latest generation RAS thus reduce water consumption, and $\mathrm{NO}_{3}$ and organic matter discharge. The costs for installation and operation of the denitrification reactor are outweighed by the reduction in costs for discharge to the local sewer, groundwater permits restricting groundwater extraction at one production location and the increasing energy costs for heating groundwater to $28{ }^{\circ} \mathrm{C}$ (Martins et al., 2009b).

Considering the nutrient balance before and after on-farm implementation of denitrification on the hypothetical $100 \mathrm{MT} / \mathrm{y}$ tilapia farm mentioned before (Eding et al., 2009), performance of a $100 \mathrm{MT} / \mathrm{y}$ tilapia RAS with and without denitrification was compared for the sustainability parameters nutrient utilization efficiency (\%), resource use and waste discharge per $\mathrm{kg}$ fish produced (Table 4). It can be seen that the RAS with denitrification has substantially lower requirements for heat, water and bicarbonate. Although the RAS with denitrification has somewhat higher requirements for electricity, oxygen and labour (and investments), the actual production costs per $\mathrm{kg}$ harvested fish are approximately $10 \%$ lower than for the conventional RAS. Waste discharge is reduced by integration of denitrification by $81 \%$ for nitrogen $(\mathrm{N}), 59 \%$ for chemical oxygen demand (COD), 61\% for total oxygen demand (TOD), $30 \%$ for $\mathrm{CO}_{2}$ and $58 \%$ for total dissolved solids (TDS).

Integrating a USB-denitrification reactor in a conventional RAS allows to (1) reduce the make-up water volume necessary for $\mathrm{NO}_{3}$ control, (2) reduce $\mathrm{NO}_{2}$ discharge, (3) reduce energy consumption due to heat production by the bacterial biomass in the reactor and a reduction in the volume of make-up water that needs to be heated, (4) concentrate and reduce the drum filter solids flow, by digesting the solids in situ, reducing fees for discharge of TAN, $\mathrm{NO}_{3}$, organic nitrogen, and organic matter (measured as COD), and (5) increase alkalinity allowing a pH neutral fish culture operation. Kim and Bae, 2000 E.W. Kim and J.H. Bae, Alkalinity requirements and the possibility of simultaneous heterotrophic denitrification during sulfur utilizing autotrophic denitrification, Water Sci. Tech. 42 (2000), pp. 233-238. View Record in Scopus | Cited By in Scopus (24)

Despite the considerable advantages of introducing a denitrification reactor in a conventional RAS, its use in commercial farming is still limited. Major reasons include the higher 
investments, the required expertise and the accumulation of TDS on farm or the alternative use of an external carbon source. In most EU countries, the economical feasibility of using a denitrification reactor still has to be demonstrated.

One of its major contributions to environmental sustainability of integrating denitrification in RAS is the reduction in water use. However, a small water exchange rate might also create problems. As pointed out by Martins et al (2009 a,b) such reduction may lead to an accumulation of growth inhibiting factors originating from the fish (e.g. cortisol), bacteria (metabolites) and feed (metals). Using a bioassay, Martins et al. (2009a) showed that with a low water exchange of $30 \mathrm{~L}$ per $\mathrm{kg}$ feed, the accumulation of phosphate $\left(\mathrm{PO}_{4}\right), \mathrm{NO}_{3}$ and of the heavy metals arsenic and copper is likely to impair the embryonic and larval development of common carp and therefore deserves further research. Also, Davidson et al. (2009) suggested a negative impact on survival of reducing water refreshment rates in trout cultured in RAS, mainly due to the accumulation of copper. Nevertheless, in grow out, Good et al. (2009) and Martins et al. (2009b) showed no impact on growth performance of fish cultured in low water exchange RAS. In turbot RAS no growth retardation could be detected compared to re-use of flow through systems during long term experiments (about 550 days) running those systems under commercial conditions (Schram et al., 2009)

\subsubsection{Sludge thickening technologies}

Sludge discharge from RAS requires storage facilities, transportation, labour and disposal fees (Schneider et al., 2006). Thickening technologies such as belt filter systems (Ebeling et al., 2006) and geotextile bags or tubes (Ebeling et al., 2005; Sharrer et al., 2009) can decrease this problem. These systems allow a dewatering of the sludge and therefore a reduction in the volume of solids produced.

Sharrer et al. (2009) suggested that using geotextile bag filters in RAS provide an excellent pretreatment in situations where the total suspended solids (TSS) must be dewatered before disposal, because 1) leaching of dissolved organic carbon and COD from this waste is desired to drive denitrification or 2) leaching of inorganic nitrogen and $\mathrm{PO}_{4}$ from the waste is desired to feed nutrients to downstream hydroponic operations or field crops (Ebeling et al., 2006). In addition, when geotextile tubes are incorporated in a RAS + denitrification reactor system, the solids waste volume could be concentrated to a dry matter content of $9.1 \%$ after 7 days of dewatering when supplying polymer as coagulation/flocculation aid to the weekly discharged sludge from the denitrification reactor (Eding et al., 2009). However, results within the scope of the AquaEtreat project (http://www.aquaetreat.org) showed that the use of polymer for trout sludge thickening was too expensive for ensuring sustainable production in France and Italy.

Phosphorus is one of the nutrients contributing most to the eutrophication of waters receiving effluents from intensive aquaculture. Therefore, any reduction in phosphorus levels in aquaculture effluents will improve the environmental sustainability of RAS. Targeting to further improve the solid removal efficiency from RAS is a logical first step as the filterable or settleable solids fractions of aquaculture effluents contain the highest fraction of discharged $P$ (Heinen et al., 1996). Rishel and Ebeling (2006) using a combination of alum/polymer in a flocculation unit obtained removal rates $>90 \%$ for TSS, $\mathrm{PO}_{4}$, total phosphorus (TP), biological oxygen demand (BOD) and COD from aquaculture effluents. These authors also showed an effect of the coagulation/flocculation aids on the nitrogen removal: TAN, $\mathrm{NO}_{3}$, $\mathrm{NO}_{2}$, and total nitrogen (TN) in the wastewater effluent were reduced on average by 64,50 , 68 , and $87 \%$, respectively. 


\subsubsection{Ozone}

Ozone has been used in RAS to control pathogens (e.g. Bullock et al., 1997) and to oxidize $\mathrm{NO}_{2}$ to $\mathrm{NO}_{3}$, organic matter, TAN, or fine suspended particles (e.g. Tango and Gagnon, 2003; Summerfelt et al., 2009). Ozonation improves microscreen filter performance and minimizes the accumulation of dissolved matter affecting the water colour (Summerfelt et al., 2009). Generally a wide range is referred in literature, 3- $24 \mathrm{~g}$ ozone for every $\mathrm{kg}$ of feed to a RAS, to sustain good water quality and fish health (Bullock et al., 1997; Summerfelt, 2003). However, ozonation by-products could be harmful. Bromate is one of such by-products and potentially toxic. Tango and Gagnon (2003) showed that ozonated marine RAS have concentrations of bromate that are likely to impair fish health. Therefore, the consequences to the fish of applying ozone in RAS should be further investigated.

\subsection{New approaches towards integrated systems}

Although strictly spoken, a RAS should minimally contain one fish tank and one water treatment unit, sometimes a stagnant aquaculture pond is referred to as a single reactor RAS. All processes managed in separate reactors in RAS also occur in ponds: algae or macrophyte production, sedimentation, nitrification, denitrification, acidification, phosphate precipitation, aerobic and anaerobic decomposition, fish production, heating or cooling, etc. By compartmentalizing some of these processes in reactors besides the fish tank the total production capacity of the system is increased (Verdegem et al., 1999; Schneider et al., 2005; Gál et al., 2007). However the overall treatment efficiency using especially phototrophic reactors is currently still too low and leads to a mismatch in surface areas between fish production and phototrophic reactor by at least one magnitude (Schneider et al., 2002). The re-use of this biomass as feed is again decreasing the overall efficiency of the treatment process by $90 \%$.

Recently, wetlands and algal ponds received a lot of attention as water treatment units in RAS, as they contribute to the water reuse in the system.

\subsubsection{Wetlands}

Effluents from fish tanks, ponds or raceways are 20-25 times more diluted than medium strength municipal wastewater commonly treated in constructed wetlands (Vymazal, 2009). Wetlands are mostly used to treat aquaculture effluents after concentrating the wastes, at which point they are considered a low cost and viable biological treatment method (SipaúbaTavares and Braga, 2008). Kerepeczki et al. (2003) directly treated the effluent from an intensive African catfish operation, passing the effluent first through carp ponds and subsequently through ponds converted into wetland. In this pond-wetland system, removal rates above $90 \%$ were obtained for TAN, $\mathrm{PO}_{4}$ and organic suspended solids and between 65 and $80 \%$ for inorganic nitrogen compounds, TN and TP. The removal rate of $\mathrm{NO}_{3}$ was $38 \%$. Most constructed wetlands used in aquaculture are soil based horizontal subsurface flow systems. Reviewing 20 years operation of this type of constructed wetlands in Denmark, Brix et al. (2007) concluded that the BOD and organic matter reduction is excellent, but that the removal of $\mathrm{N}$ and $\mathrm{P}$ is typically only $30-50 \%$. In addition, nearly no nitrification occurs in these horizontal subsurface flow systems. To reduce the TAN concentration in the effluent to $<2$ $\mathrm{mg} / \mathrm{L}$, a fixed film aerated nitrification filter needed to be added. In recent years, to improve TAN and $\mathrm{NO}_{3}$ removal, newly installed systems are vertical flow constructed wetlands with partial recirculation. Partial recirculation of the effluent stabilizes system performance, and enhances nitrogen removal by denitrification (Arias et al., 2005). Nevertheless, Summerfelt et al. (1999) compared a vertical and horizontal flow constructed wetland to treat the concentrated solids (5\% dry matter) discharge from a trout farm. The vertical flow wetland performed better for total COD and dissolved COD removal, but both type of wetlands performed equally well for total Kjeldahl nitrogen, TP and $\mathrm{PO}_{4}$ removal. Apparently, numerous factors influence the performance of constructed wetlands for effluent treatment. 
Plant species and sediment type are important in determining the treatment efficiency of constructed wetlands. Rhizome forming plants are less efficient in removing TAN and $\mathrm{NO}_{3}$ than plants forming fibrous roots (Chen et al., 2009). Plants mainly affect the removal of organic matter and $\mathrm{N}$ species, while sediments like steel slag or limestone are excellent for $\mathrm{P}$ removal (Naylor et al., 2003). Testing different combinations of plant species and sediment types to treat a fish farm effluent from an anaerobic digester, it was impossible to maximize in one step simultaneous removal of organic matter, nitrogen and phosphorous. The recommendation was given to use two sequential units, first a macrophyte planted basin with a neutral substrate, followed by a plant-free basin with a phosphorous absorbing substrate. A similar approach was followed by Comeau et al. (2001) to treat the effluent from a $60 \mu \mathrm{m}$ screen drum filter on a trout farm. By passing the effluent first through a plant bed, then through a phosphorous removing bed more than $80 \%$ of the TP mass load and $95 \%$ of the suspended solids were removed.

The nutrient removal efficiency in constructed wetlands of non-concentrated aquaculture effluents tends to be lower than for concentrated effluents. On average, $68 \%$ of COD, 58\% TP and $30 \%$ of TN were removed from trout raceway effluents in a constructed wetland, applying a hydraulic retention time of $7.5 \mathrm{~h}$ (Schulz et al. 2003). In a recent study, Sindilariu et al. (2009a) removed up to $75-86 \%$ of TAN, BOD $_{5}$ and TSS with a uptake of 2.1-4.5 g TAN and $30-98 \mathrm{~g} \mathrm{TSS} / \mathrm{m}^{2} / \mathrm{d}$, from trout raceway effluents. With a cost of $€ 0.20 / \mathrm{kg}$ fish, which is less than $10 \%$ of the total production costs, subsurface flow constructed wetlands to treat trout farm effluents are considered commercially viable.

Reports of integration of constructed wetlands in partially recirculating fish farms in Europe are rare (Andreasen, 2003; Summerfelt et al., 2004). Water re-use involves costs for pumping and aeration or oxygenation. Advantages include more fish produced per $\mathrm{m}^{3}$ of water entering the farm and the possibility to remove and concentrate solids from the recirculating flow. In a commercial trout farm, the farm effluent returning to the brook from where it was taken was only enriched with $0.03 \mathrm{mg} / \mathrm{L} \mathrm{TP}, 1.09 \mathrm{mg} / \mathrm{L} \mathrm{BOD}$ and $0.57 \mathrm{mg} / \mathrm{L}$ TSS (Sindilariu et al., 2009b). To achieve this, a combination of screen filtration and extraction of sludge for agriculture manure application in a cone settler was used. The supernatant from the cone settler was led through a subsurface constructed wetland prior to discharge. On average, $64 \%$ of the particulate matter, $92 \%$ of $\mathrm{NO}_{2}$ and $81 \%$ of $\mathrm{NO}_{3}$ were removed in the constructed wetland.

\subsubsection{Algal controlled systems}

\section{Micro-algae availability}

Aquaculture ponds are eutrophic with a primary production of $1-3 \mathrm{~g} \mathrm{C} / \mathrm{m}^{2} / \mathrm{d}$ in temperate regions and 4-8 $\mathrm{g} \mathrm{C} / \mathrm{m}^{2} / \mathrm{d}$ in the tropics and subtropics. Nearly all algae are mineralized within the pond. In addition, aquafeeds also act as a fertilizer. If the total primary production would constantly be harvested from ponds, the amount of fertilizer needed to maintain the productivity would be prohibitively high. Pond management aims to maintain production and consumption in equilibrium. Nevertheless, even if only a few \% of the primary production could be harvested and used as feed or biofuel (Cadoret and Bernard, 2008), the impact on the biobased economy would be significant. Direct harvesting of algae is difficult. New techniques like flocculation maybe will lead to a breakthrough (Lee et al., 2009).

\section{Micro-algae based water treatment}

Microalgae are used in waste water treatment, supporting the removal of COD and BOD, nutrients, heavy metals and pathogens, and anaerobic digestion of algal-bacterial biomass can produce biogas (Muñoz and Guieysse, 2006). Also dissolved aquaculture wastes can be processed in algal ponds. In turn, the produced algal biomass represents a food resource for 
a selected number of aquatic species. Wang (2003) reported on a commercial integrated shrimp - algae - oyster culture in Hawaii with reduced water consumption that turns effluent treatment into a profit. The farmer was able to maintain a relatively pure outdoor culture of Chaetoceros sp. as food for the oyster Crassostrea virginica. A major difficulty is to maintain the balance between shrimp, algae and oyster populations. Constant filter feeding by the oysters on Chaetoceros is necessary to keep the algae population healthy. A high concentration of Chaetoceros helps in reducing pathogens like Vibrio vulnificus for the shrimp. Other systems utilizing phototrophic conversions have been summarized and compared in Schneider et al. (2005).

High-rate algal ponds (HRAP) have been designed to match the production of algae and $\mathrm{O}_{2}$ with the BOD of the influent (Oswald, 1988). HRAPs can remove up to $175 \mathrm{~g} \mathrm{BOD} / \mathrm{m}^{3} / \mathrm{d}$, compared to 5-10 g BOD for normal (waste stabilization) ponds (Racault and Boutin, 2005). A slightly modified concept of HRAPs has been applied for waste treatment in partitioned aquaculture systems (PAS) (Brune et al., 2003). American catfish production is concentrated in raceways in a small fraction of the pond, from where the water passes through a sedimentation basin and subsequently through a shallow algal raceway. Nile tilapias are stocked in the algal section to reduce the algal density. The tilapias filter algae from the water column, reduce the prevalence of blue green algae increasing the presence of green algae, and trap algae in fecal pellets that are easily removed from the water column. Considerable more American catfish is produced in PAS per unit surface area than in conventional ponds. Fine tuning the oxygen dynamics in the systems requires continuous monitoring and highly skilled management, constraining large scale adaptation of PAS technology.

In France, a HRAP was incorporated in a sea bass RAS as a secondary waste water treatment to reduce the discharge of nutrients from the system (Deviller et al., 2004; Metaxa et al., 2006) and reuse the waste water into the RAS. Fish growth was similar in RAS with and without reuse of the water purified in the HRAP. The HRAP treated water had limited effect on the overall functioning of the RAS, but survival was better in the RAS+HRAP system. The concentration of inorganic nitrogen and phosphorous was less in the rearing water of the RAS+HRAP system, while the accumulation of metals in muscle and liver of the sea bass was reduced, except for chromium and arsenic.

Open pond sea bass, sea bream and turbot production units were developed in previous salt ponds along the Atlantic coast in Europe. The continuous culture of microalgae using pond effluents is possible with the continuous addition of the limiting nutrients silicon and phosphorus to obtain a 10N:5Si:1P ratio (Hussenot et al., 1998; Hussenot, 2003). When the hydraulic retention time is adjusted to the temperature dependent growth rate of the algae, $67 \%$ of TAN and $47 \% \mathrm{PO}_{4}$ can be removed. For intensive hatchery-nursery systems, in-pond submerged foam fractionation was used, effectively removing dissolved organic carbon and bacteria, and to a lesser extend chlorophyll and $\mathrm{PO}_{4}$. The foam fractionation works well in low water exchange ponds, but is not effective in flow-through systems.

\section{Looking ahead: priorities for future research}

The basic RAS technology seems quite out-engineered, yet, there are many technical innovations needed to enable the systems performing well for a broader range of animals, culture conditions and life stages. Current engineering innovations search for more energy and cost efficient systems, more closed systems, and/or for a cradle-to-cradle approach in system development, whereby wastes are re-used for other purposes or product commodities. Automation, robotisation, and cybernetic control systems are still far from being commonly used but could provide breakthrough innovations. Next to this pure engineering approach, it is envisaged that major breakthroughs have to come from a better understanding of how the animals interact with the RAS biotope. Such understanding may contribute to minimize even further the ecological impact of RAS. 
The major area of research that we foresee as priority to improve the ecological sustainability of RAS is the efficiency of waste removal (solids, nitrogen, phosphate) in the system.

\subsection{Solids}

Current RAS systems are reasonably well designed to manage nitrogenous wastes and gaseous exchange, but not to manage solid wastes. The main bottleneck is related in the fine solids produced in the system, which are insufficiently removed from the water with the currently available techniques (Losordo et al., 1999; Chen et al. 1996; Chen et al. 1997). A high concentration of suspended solids has a negative influence on nitrification, water quality (Eding et al., 2006) and fish growth (Davidson et al., 2009). The problem can be reduced by adjusting the source of the nutrients, i.e. the feeds and the feeding strategies, the design of the tanks and their hydraulic characteristics, and the efficiency of the solids removal systems. Research priorities include:

- Avoid feed spillage. This requires studies on feed intake regulation and on feeding strategies for RAS.

- Increase feed efficiency. This relates to more classic nutrition studies. The potential gain is less apparent, but, especially because of the significant changes to be expected in the used resources, it remains very important to take the digestibility and utilization of feed ingredients into account when developing specific RAS diets.

- Optimization of the consistency, water stability and composition of the faeces. The targeted outcome of this line of studies is to produce faeces which can be easily removed from the water, produce less fine solids, and when produced can be easily fermented by the microbial community in the system. Recent studies start to shed some light into these interactions. Amirkolaie et al. (2006) showed that a higher inclusion of starch in the diet of Nile tilapia resulted in a higher viscosity of the digesta which contributed to higher faeces removal efficiency in the RAS. These authors also showed that the degree of gelatinization in the diet affects faeces removal rate. In another study, Amrikolaie et al. (2005) showed that the inclusion on insoluble non-starch polysaccharide (cellulose) in the diet also improve the removal efficiency of particles in RAS by increasing faeces recovery. Brinker (2007) also showed that supplementing rainbow tour feed with highviscosity guar gum resulted in improved faecal stability and an increase of the mechanical treatment efficiency (Brinker et al., 2005). The above studies call for more 
- Technology development and implementation for (fine) solids removal. Most freshwater systems use drum filters or similar devices to filter larger solids particles from the tank effluents and rely on subsequent fixed bed bio-filters to remove the fine solids (Losordo et al., 1999). In marine RAS, drum filters or equivalent devices are often combined with foam fractionation systems (protein skimmers) to improve the fine suspended solids removal. Until today, there is no unambiguous and clear answer how to control and remove the different solids fractions in a cost effective and treatment efficient way. Further, the hydraulic characteristics within the rearing tank and the solids removal system affect the efficiency of solids removal (Klapsis and Burley, 1984; Losordo et al., 1999). Technology innovations in this area should take tank design, solids removal system and the hydraulic conditions into account. Finally, in marine RAS, ozone is often used to improve the water quality in the system (Suantika et al., 2001; Tango and Gagnon, 2003; Wolters et al., 2009). Ozone may alter the characteristics of the fine solids (Tango and Gagnon, 2003), thereby improving the effectiveness of the foam fractionators in the system. However, the interaction still needs further research.

\subsection{Nitrogen}

In most RAS systems, nitrogen is removed by a combination of moving bed and fixed bed nitrification reactors and, in some cases, additional denitrification reactors (Losordo et al., 1999). The nitrification process in RAS is hampered by the level of organic matter entering the bio-filters (Eding et al., 2006). As a result, both autotrophic and heterotrophic bacteria are growing in the reactors. The challenge is to enable nitrification reactors to work as chemoautotrophic as possible, e.g., by minimizing the organic carbon (OC) in the influent of the nitrification reactor. Therefore, major objectives for research are:

- Separate the OC and TAN removal in different treatment steps;

- Make a mixed reactor, in which OC and TAN removal are combined. In such a reactor, the first part of the reactor will focus on OC removal, the second part on TAN removal;

- To continue research on constructed wetland technologies (e.g. PROPRE project) 
In contrast, a denitrification reactor in RAS requires and influent with a high C: $\mathrm{N}$ ratio (van Rijn, 2006). Often external carbon sources are used, such as methanol, ethanol or glucose (Sauthier et al., 1998). Ongoing research explores possibilities to use internal carbon sources (e.g., the solid waste produced by the fish, Klas et al., 2006). This is a spectacular development because it provides the theoretical perspective to close a RAS to nearly $100 \%$ from an ecological point of view. Furthermore, the incorporation of a denitrification reactor in freshwater RAS has been predicted to reduce cost price by $10 \%$ despite the higher investment and operating costs (Eding et al., 2009). However, the technology is still immature and the cost effectiveness needs to be better understood.

New purification technologies, such as the anaerobic ammonium-oxidizing (Anammox) technology, which converts TAN directly into nitrogen gas (e.g. Gut et al., 2006, van Rijn et al., 2006), deserve to be fully tested and their feasibility for RAS needs to be investigated. The limited number of studies using this purifying technology in RAS (Tal et al., 2006, 2009) shows promising results. Tal et al. (2009) using Anammox achieved 99\% water recycling in a marine RAS.

Worth noting is also the recent development of granular sludge systems (Yilmaz et al., 2008; Di laconi et al., 2010) that could be particularly interesting in combining simultaneously nitrification, denitrification and P-removal in one single system.

In addition, the microbial ecology of the nitrification/denitrification reactor systems in RAS deserves also further study. It is believed that fundamental research in this area may provide innovations which may alter and/or improve the reactor performance in RAS drastically. Until today, the microbial community in reactors is difficult to control (Leonard et al., 2000, 2002; Michaud et al., 2006, 2009; Schreier et al., 2010) and many of the inefficiencies of the system originate from this.

Research priorities to improve the denitrification process in RAS include:

- Design systems in which nutrient inputs (feeds) optimize concurrently fish growth and welfare, and water purification (waste removal andnitrification/denitrification performance).

- Develop denitrification systems using the internal RAS sludge as carbon source

- Explore the possibility to steer microbial communities in RAS 


\subsection{Phosphate}

Partly as a result of prevailing water management and legislation in most EU member states, most current RAS do not focus on specific phosphate removal systems, leading to accumulation of $\mathrm{PO}_{4}$ in the system water and relative high P levels in the RAS effluents (e.g. Martins et al., 2009a). The efficiency and cost effectiveness of phosphate removal is one of the most important barriers. Controlling phosphate levels is possible through one or a combination of the following methods:

- Optimizing P-retention in the fish

- Fast removal of solids from the water (to avoid leaching of phosphorus from the organic matrix)

- Dephosphatation techniques. At this moment, only classic chemical flocculation (dephosphatation) is well established in freshwater RAS (e.g. Kamstra et al., 2001).

- Integrated multi-trophic aquaculture, IMTA (end-of-the-pipe treatment by recycling phosphorus in other commodities, (e.g. Metaxa et al., 2006; Muangkeow et al., 2007).

Because of the expected future shortage in world phosphate resources, recycling and saving phosphorus should be a top research priority. When RAS are integrated in an integrated agriculture-aquaculture system (for example, with greenhouse cultures, e.g. http://www.ecofutura.nl/theproject.htm, http://www.vigourfishion.nl/index.php/,http://attra.ncat. org/attra-pub/PDF/aquaponic.pdf, Savidov et al., 2007), feeds should be adjusted in such a way, that all waste exported to the greenhouse plants, is easily mineralized and assimilated by the plants. This calls for feed formulations using nutrient digestibility and utilization data in fish together with nutrient assimilation data from the target plants.

\section{Conclusions}

'Producing more food from the same area of land while reducing the environmental impacts requires what has been called sustainable intensification" wrote Godfray et al. (2010) in a recent review about the challenge of feeding 9 billion people. The key question is how can more food (in the scope of this review, more fish) be produced sustainably? Considering all aquaculture production systems in use today, RAS offers the possibility to achieve a high production, maintaining optimal environmental conditions, securing animal welfare, while creating a minimum ecological impact. At present, the use of RAS is growing in Europe, for grow-out of freshwater (eel and catfish) and marine species (turbot, seabass and sole) but also for fingerling production of both freshwater and marine species. Recent research aiming to improve water treatment efficiency (denitrification reactors, sludge thickening technologies and ozone) allows reducing water refreshment rates, creating nearly closed systems, producing a small quantity of an easy to treat and valuable waste product for use in IAA or IMTA systems. Despite the recent developments that will certainly foster the environmental sustainability of RAS, the potential accumulation of substances in the water as a consequence of reduced water refreshment rates may pose new challenges. A deeper understanding of the interaction between the fish and the system will help facing these challenges. 


\section{Acknowledgements}

C.I.M. Martins was supported by a grant provided by the Foundation for Science and Technology, Portugal (SFRH/BPD/42015/2007). Further financial support came from the Dutch Ministry of Agriculture, Nature Conservation and Food Quality (LNV bestek Duurzame viskweek Ond/2005/08/01) and the SUSTAINAQUA project (co-funded by the European Commission; for more details on the project and its twenty-three partners visit www.sustainaqua.org).

\section{References}

Amirkolaie, A.K., Leenhouwers, J.I., Verreth, J.A.J., Schrama, J.W., 2005. Type of dietary fibre (soluble versus insoluble) influences digestion, faeces characteristics and faecal waste production in Nile tilapia (Oreochromis niloticus L.) Aquacult. Res. 36, 1157-1166.

Amirkolaie, A.K., Verreth, J.A.J., Schrama, J.W., 2006. Effect of gelatinization degree and inclusion level of dietary starch on the characteristics of digesta and faeces in Nile tilapia (Oreochromis niloticus (L.)) Aquaculture 260, 194-205.

Andreasen, A., 2003. Neue Technoligie- und Produktionsformen in Dänemark. BioMar Magazin 2, 3-5.

Arias, C. A., Brix, H., Marti, E., 2005. Recycling of treated effluents enhances removal of total nitrogen in vertical flow constructed wetlands. J. Environ. Sci. Health - Part A, 40, 1431-1443. Aubin, J., Papatryphon, E., Van der Werf, H.M.G., Petit, J., Morvan, Y.M., 2006. Characterisation of the environmental impact of a turbot (Scophthalmus maximus) recirculating production system using Life Cycle Assessment. Aquaculture 274,72-79.

Aubin, J., Papatryphon, E., Van der Werf, H.M.G., Chatzifotis, S., 2009. Assessment of the environmental impact of carnivorous finfish production systems using life cycle assessment.

J. Cleaner Prod. 17, 354-361.

Ayer, N.W., Tyedmers, P.H., 2009. Assessing alternative aquaculture technologies: life cycle assessment of salmonid culture systems in Canada. J Cleaner Prod. 17, 362-373.

Barak, Y., 1998. Denitrification in recirculating aquaculture systems: From biochemistry to biofilters. Proceedings of the Second International Conference on Recirculating Aquaculture, Virginia, USA, Virginia Sea Grant.

Bergheim, A., Drengstig, A., Ulgenes, Y, .and Fivelstad,S., 2008. Dominating Systems for Production of Atlantic Salmon Smolt in Europe Proceedings of the Aquacultural Engineering Society's Fourth Issues Forum. 59-72.

Bergheim, A., Drengstig, A., Ulgenes, Y., Fivelstad, S., 2009. Production of Atlantic salmon smolts in Europe-Current characteristics and future trends. Aquacult. Eng. 41, 46-52.

Blancheton J.P., Piedrahita, R., Eding, E.H., Roque d'Orbcastel, E., Lemarié, G., Bergheim, A., Fivelstad, S., 2007. Intensification of land based aquaculture production in single pass and reuse systems. Aquacultural Engineering and Environment, Asbjorn Bergheim (Ed.). Research Signpost, Kerala, India, p. 21-47.

Brinker, A., Koppe, W., Rösch, R., 2005. Optimised effluent treatment by stabilised trout faeces. Aquaculture. 249, 125-144.

Brinker, A., 2007. Guar gum in rainbow trout (Oncorhynchus mykiss) feed: The influence of quality and dose on stabilisation of faecal solids. Aquaculture. 267, 315-327.

Brix, H., Schierup, H. H., Arias, C. A., 2007. Twenty years experience with constructed wetland systems in Denmark - What did we learn? Water Sci. Technol. 56, 63-68.

Brune, D. E., Schwartz, G., Eversole, A. G., Collier, J. A., Schwedler, T. E., 2003. Intensification of pond aquaculture and high rate photosynthetic systems. Aquacult. Eng. 28, 65-86. 
Bullock, G.L., Summerfelt, S.T., Noble, A.C., Weber, A.L., Durant, M.D., Hankins, J.A., 1997. Ozonation of a recirculating rainbow trout culture system. I. Effects on bacterial gill disease and heterotrophic bacteria. Aquaculture 158, 43-55.

Buschmann, A.H., Riquelme, V.A., Hernández-González, M.C., Varela, D., Jiménez, J.E., Henríquez, L.A., Vergara, P.A., Guíñez, R., Filún, L., 2006. A review of the impacts of salmonid farming on marine coastal ecosystems in the southeast Pacific. ICES J. Mar. Sci. $63,1338-1345$.

Cadoret, J.-P., Bernard, O., 2008. Lipid biofuel production with microalgae: Potential and challenges. Journal de la Société de Biologie. 202, 201-211.

Chen, S., Ning, Z., Malone, R. F., 1996. Aquaculture sludge treatment using an anaerobic and facultative lagoon system. International conference on recirculation technology, Roanoke, Virginia, Virginia-Tech.

Chen, S., Stechey, D., Malone, R. F., 1997. Suspended solids control in recirculating aquaculture systems. Aquaculture water reuse systems: Engineering design and management. M. B. Timmons and T. M. Losordo. Amsterdam, The Netherlands, Elsevier. 27: 61-100.

Cheng, X. Y., Chen, W. Y., Gu, B. H., Liu, X. C., Chen, F., Chen, Z. H., Zhou, X. Y., Li, Y. X., Huang, H., Chen, Y. J., 2009. Morphology, ecology, and contaminant removal efficiency of eight wetland plants with differing root systems. Hydrobiologia. 623, 77-85.

Comeau, Y., Brisson, J., Réville, J. P., Forget, C., Drizo, A., 2001. Phosphorus removal from trout farm effluents by constructed wetlands. Water Sci. Technol. 44, 55-60.

Davidson, J., Good, C., Welsh, C., Brazil, B., Summerfelt, S., 2009. Heavy metal and waste metabolite accumulation and their potential effect on rainbow trout performance in a replicated water reuse system operated at low or high system flushing rates Aquacult. Eng. 41, 136-145.

del Campo, L.M., Ibarra, P., Gutiérrez, X., Takle, H., 2010. Utilization of sludge from Recirculation aquaculture systems. Nofina report 9/2010. 73pp.

Deviller, G., Aliaume, C., Nava, M. A. F., Casellas, C., Blancheton, J. P., 2004. High-rate algal pond treatment for water reuse in an integrated marine fish recirculating system: Effect on water quality and sea bass growth. Aquaculture. 235, 331-344.

Di laconi, C., De Sanctis, M., Rossetti, S., Ramadori, R., 2010. SBBGR technology for minimising excess sludge production in biological processes. Water Res. 44, 1825-1832.

Ebeling, J.M., Schwartz, M.F., Rishel, K.L., Summerfelt, S.T., 2005. Dewatering aquaculture biosolids with geotextile bags. Aquaculture America 2005. p231

Ebeling, J.M., Welsh, C.F., Rishel, K.L., 2006. Performance evaluation of an inclined belt filter using coagulation/flocculation aids for the removal of suspended solids and phosphorus from microscreen backwash effluent Aquacult. Eng. 35, 61-77.

Eding, E. H., Kamstra, A., 2002. Netherlands farms tune recirculation systems to production of varied species. Global Aquaculture Advocate 5, 52-54.

Eding, E.H., Kamstra, A., Verreth, J.A.J., Huisman, E.A., Klapwijk, A., 2006. Design and operation of nitrifying trickling filters in recirculating aquaculture: A review. Aquacult. Eng. 34, 234-260.

Eding, E., Verdegem, M., Martins, C., Schlaman, G., Heinsbroek, L., Laarhoven, B., Ende, S., Verreth, J., Aartsen, F., Bierbooms,V., 2009. Tilapia farming using Recirculating Aquaculture Systems (RAS) - Case study in the Netherlands, in a handbook for sustainable Aquaculture, Project N: COLL-CT-2006-030384, http://www.sustainaqua.org/

Ellingsen, H., Olaussen, J.O., Utne, I.B., 2009. Environmental analysis of the Norwegian fishery and aquaculture industry - A preliminary study focusing on farmed salmon. Mar. Policy. 33, 479-488.

Gál, D., Pekár, F., Kerepeczki, E.,Váradi, L., 2007. Experiments on the operation of a combined aquaculture-algae system. Aquacult. Int. 15, 173-180. 
Godfray, H.C.J., Beddington,J.R.,Crute,I.R., Haddad,L., Lawrence, D., Muir,J. F., Pretty, J., Robinson, S.,Thomas, S.M., Toulmin, C., 2010. Food Security: The Challenge of Feeding 9 Billion People. Science 327, 812-818.

Good, C., Davidson, J., Welsh, C., Brazil, B., Snekvik, K., Summerfelt, S., 2009. The impact of water exchange rate on the health and performance of rainbow trout Oncorhynchus mykiss in water recirculation aquaculture systems. Aquaculture 294, 80-85

Gut, L., Płaza, E., Trela, J., Hultman, B., Bosander, J., 2006. Combined partial nitritation/Anammox system for treatment of digester supernatant. Water Sci. Technol. 53, 149-159.

Heinen, J.M., Hankins, J.A., Adler, P.R., 1996. Water quality and waste production in a recirculating trout- culture system with feeding of a higher-energy or a lower-energy diet. Aquacult. Res. 27, 699-710.

Hussenot, J., Lefebvre, S., Brossard, N., 1998. Open-air treatment of wastewater from landbased marine fish farms in extensive and intensive systems: Current technology and future perspectives. Aquat. Living Resour. 11, 297-304.

Hussenot, J. M. E., 2003. Emerging effluent management strategies in marine fish-culture farms located in European coastal wetlands. Aquaculture. 226, 113-128.

Hussenot, J., 2006. Les systèmes intégrés en aquaculture marine : une solution durable pour un meilleur respect de l'environnement littoral. In : Chaussade J, Guillaume J, eds. Pêche et aquaculture : pour une exploitation durable des ressources vivantes de la mer et du littoral. Rennes: Presses Universitaires de Rennes, 2006.

ISO, 2006. ISO 14044:2006 Environmental management -- Life cycle assessment -Requirements and guidelines.

Joensen, R., 2008. Resirkulering av vand i oppdrett. Presentation at Seminar of Recirculation of Water in Aquaculture, 27-28 February 2008, Sunndalsøra, Norway (In Danish).

Jokumsen, A., Pedersen, P.B., Dalsgaard, A. J. T., Lund, I., Paulsen, H., Rasmussen, R. S., Grethe Hyldig, G., Lisbeth, J., Plessner, L. J., Michelsen, K., Laursen, C., 2009. New methods in trout farming to reduce the farm effluents - Case study in Denmark. Handbook for sustainable Aquaculture, Project $\mathrm{N}^{\circ}$ : COLL-CT-2006-030384. www.sustainaqua.org

Kamstra, A., Eding E.H., Schneider, O., 2001. Top eel farm upgrades effluent treatment in Netherlands. Global Aquaculture Advocate. 4, 37- 38.

Kerepeczki, A., Gal, D., Szabó, P., Pekár, F., 2003. Preliminary investigations on the nutrient removal efficiency of a wetland-type ecosystem. Hydrobiologia. 506-509, 665-670.

Kim, E.W., Bae, J.H., 2000. Alkalinity requirements and the possibility of simultaneous heterotrophic denitrification during sulfur-utilizing autotrophic denitrification. Water Sci. Technol. 42, 233-238.

Klapsis, A., Burley, R., 1984. Flow distribution studies in fish rearing tanks. Part 1 - Design constraints Aquacult. Eng. 3, 103-118

Klas, S., Mozes, N., Lahav, O., 2006. Development of a single-sludge denitrification method for nitrate removal from RAS effluents: Lab-scale results vs. model prediction. Aquaculture 259, 342-353.

Kristensen, T., Åtland, Å., Rosten, T., Urke, H. A., Rosseland, B. O., 2009. Important influentwater quality parameters at freshwater production systems in two salmon producing countries. Aquacult. Eng. 41, 53-59.

Lee, A. K., Lewis, D. M. , Ashman, P. J., 2009. Microbial flocculation, a potentially low-cost harvesting technique for marine microalgae for the production of biodiesel. J Appl. Phycol. 21, 559-567.

Leonard, N., Blancheton, J.P., Guiraud, J.P., 2000. Populations of heterotrophic bacteria in an experimental recirculating aquaculture system. Aquacult. Eng. 22, 109-120.

Leonard, N., Guiraud, J.P., Gasset, E., Cailleres, J.P., Blancheton, J.P., 2002. Bacteria and nutrients - Nitrogen and carbon - In a recirculating system for sea bass production. Aquacult. Eng. 26, 111-127.

Losordo, T. M., 1998a. Recirculating aquaculture production systems: The status and future. Aquaculture Magazine 24(Jan./Febr.): 38-45. 
Losordo, T. M., 1998b. Recirculating production systems: The status and future, part ii. Aquaculture Magazine 24(March/April): 45-53.

Losordo, T. M., Masser, M. P., Rakocy, J. E., 1999. Recirculating aquaculture tank production systems: a review of component options. SRAC, publication no 453.

Martins, C.I.M., Eding,E.H., Schneider,O., Rasmussen, R., Olesen,B., Plesner,L., Verreth, J.A.J., 2005. Recirculation Aquaculture Systems in Europe. CONSENSUS. Oostende, Belgium, Consensus working Group, European Aquaculture Society: 31

Martins, C.I.M., Pistrin, M.G., Ende, S.S.W., Eding, E.H., Verreth, J.A.J., 2009a. The accumulation of substances in Recirculating Aquaculture Systems (RAS) affects embryonic and larval development in common carp Cyprinus carpio. Aquaculture 291, 65-73

Martins, C.I.M., Ochola, D., Ende, S.S.W., Eding, E.H., Verreth, J.A.J., 2009 b. Is growth retardation present in Nile tilapia Oreochromis niloticus cultured in low water exchange recirculating aquaculture systems? Aquaculture 298, 43-50

Masser, M.P., Rakocy, J. and Losordo, T.M., 1999. Recirculating Aquaculture Tank Production Systems: Management of Recirculating Systems. SRAC Publication No. 452, $12 \mathrm{p}$.

Metaxa, E., Deviller, G., Pagand, P., Alliaume, C., Casellas, C., Blancheton, J.P., 2006. High rate algal pond treatment for water reuse in a marine fish recirculation system: Water purification and fish health. Aquaculture. 252, 92-101.

Michaud, L., Blancheton, J.P., Bruni, V., Piedrahita, R., 2006. Effect of particulate organic carbon on heterotrophic bacterial populations and nitrification efficiency in biological filters. Aquacult. Eng. 34, 224-233.

Michaud, L., Lo Giudice, A., Troussellier, M., Smedile, F., Bruni, V., Blancheton, J.P., 2009. Phylogenetic characterization of the heterotrophic bacterial communities inhabiting a marine recirculating aquaculture system. J. Appl. Microbiol. 107, 1935-1946.

Muangkeow, B., Ikejima, K., Powtongsook, S., Yi, Y., 2007. Effects of white shrimp, Litopenaeus vannamei (Boone), and Nile tilapia, Oreochromis niloticus L., stocking density on growth, nutrient conversion rate and economic return in integrated closed recirculation system. Aquaculture 269, 363-376.

Muñoz, R., Guieysse, B., 2006. Algal-bacterial processes for the treatment of hazardous contaminants: A review. Water Res. 40, 2799-2815.

Naylor, R.L., Goldburg, R.J., Primavera, J.H., Kautsky, N., Beveridge, M.C.M., Clay, J., Folke, C., Lubchenco, J., Mooney, H., Troell, M., 2000. Effect of aquaculture on world fish supplies. Nature 405, 1017-1024.

Naylor, S., Brisson, J., Labelle, M. A., Drizo, A.,Comeau, Y., 2003. Treatment of freshwater fish farm effluent using constructed wetlands: The role of plants and substrate. Water Sci. Technol. 48, 215-222.

Papatryphon, E., Petit, J., Van der Werf, H.M.G., 2004a. The development of Life Cycle Assessment for the evaluation of rainbow trout farming in France. In: Proceedings of the 4th International Conference on Life Cycle Assessment in the Agri-feed Sector, October 6-8, 2003, Horsens, Denmark, pp.73-.80.

Papatryphon, E., Petit, J., Kaushik, S.J., Van Der Werf, H.M.G., 2004b. Environmental impact assessment of salmonid feeds using life cycle assessment (LCA). Ambio 33, 316323.

Pedersen, P.B., Svendsen,L.M., Sortkjær,O., Ovesen,N.B., Skriver,J., Larsen,S.E., Rasmussen, R.S., Johanne A., Dalsgaard, T., 2008. Environmental Benefits Achieved by Applying Recirculation Technology at Danish Trout Farms (Model Trout Farm). Proceedings of the Aquacultural Engineering Society's Fourth Issues Forum. p139

Piedrahita, R.H., 2003. Reducing the potential environmental impact of tank aquaculture effluents through intensification and recirculation. Aquaculture. 226, 35-44.

Racault, Y., Boutin, C., 2005. Waste stabilisation ponds on France: State of the art and recent trends. Water Sci. Technol. 51, 1-9.

Rijn, J., Rivera, G., 1990. Aerobic and anaerobic biofiltration in an aquaculture unit-nitrite accumulation as a result of nitrification and denitrification. Aquacult. Eng. 9, 217-234. 
Rijn, J., Barak, Y., 1998. Denitrification in recirculating aquaculture systems: From biochemistry to biofilters. Recirculating Aquaculture, Roanoke, Virginia, Virginia-Tech.

Rishel, K.L., Ebeling, J.M., 2006. Screening and evaluation of alum and polymer combinations as coagulation/flocculation aids to treat effluents from intensive aquaculture systems. J. World Aquacult. Soc. 37, 191-199.

Roque d'Orbcastel, E., 2008. Optimisation de deux systèmes de production piscicole: biotransformation des nutriments et gestion des rejets. Thèse de doctorat, INP Toulouse, Université Paul Sabatier, Toulouse III, 144 pp.

Roque d'Orbcastel, E., Person-Le-Ruyet, J., Le Bayon, N., Blancheton, J.P., 2009a. Comparative growth and welfare in rainbow trout reared in re-circulating and flow through rearing systems. Aquacult. Eng. 40, 79-86.

Roque d'Orbcastel, E., Jean-Paul Blancheton, J.P., Belaud, A., 2009b. Water quality and rainbow trout performance in a Danish Model Farm recirculating system: Comparison with a flow through system. Aquacult. Eng. 40, 135-143.

Roque d'Orbcastel, E., Blancheton, J.P., Aubin, J., 2009c. Towards environmentally sustainable aquaculture: comparison between two trout farming systems using Life Cycle Assessment. Aquacult. Eng. 40, 113-119.

Rosenthal, H., 1980. Recirculation systems in western europe. World Symposium on Aquaculture in Heated Effluents and Recirculation System, Stavanger, Institut für Kuestenund Binnefischerei, Bundesforschungsanstalt Hamburg, BRD.

Rosenthal, H., Castell, J. D., Chiba, K., Forster, J. R. M., Hilge, V., Hogendoorn, H.,Mayo, R. D., Muir, J. F., Murray, K. R., Petit, J., Wedemeyer, G. A., Wheaton, F., Wickins, J., 1986. Flow-through and recirculation systems, EIFAC: 100.

Sauthier, N., Grasmick, A., Blancheton, J.P., 1998. Biological denitrification applied to a marine closed aquaculture system. Water Res. 32, 1932-1938.

Savidov, N.A., Hutchings, E., Rakocy, J.E., 2007. Fish and plant production in a recirculating aquaponic system: A new approach to sustainable agriculture in Canada. Acta Hort. 742, 209-222.

Schuster, C., Stelz, H., 1998. Reduction in the make-up water in semi-closed recirculating aquaculture systems. Aquacult. Eng. 17, 167-174.

Schulz, C., Gelbrecht, J., Rennert, B., 2003. Treatment of rainbow trout farm effluents in constructed wetland with emergent plants and subsurface horizontal water flow. Aquaculture. 217, 207-221.

Schreier, H.J., Mirzoyan, N., Saito, K., 2010. Microbial diversity of biological filters in recirculating aquaculture systems. Curr. Opin. Biotechnol. Article in Press

Seppala, J., Silvenius, F., Gronroos, J., Makinen, T., Silvo, K., Storhammar, E., 2001. Rainbow trout production and the Environment. Finnish Environmental Institute,Helsinki,164 pp (in Finnish; abstract, tables and figures in English).

Sharrer, M.J., Rishel, K., Summerfelt, S. , 2009. Evaluation of geotextile filtration applying coagulant and flocculant amendments for aquaculture biosolids dewatering and phosphorus removal. Aquacult. Eng. 40, 1-10.

Sindilariu, P. D., Brinker, A., Reiter, R., 2009a. Factors influencing the efficiency of constructed wetlands used for the treatment of intensive trout farm effluent. Ecol. Eng. 35, 711-722.

Sindilariu, P. D., Brinker, A., Reiter, R., 2009b. Waste and particle management in a commercial, partially recirculating trout farm. Aquacult. Eng. 41, 127-135.

Sipaúba-Tavares, L. H., Braga, F. M. d. B., 2008. Constructed wetland in wastewater treatment. Acta Sci. Biol. Sci. 30, 261-265.

Schneider, O., Verreth, J., Eding, E. H., 2002. Framework introduction of zero nutrient discharge aquaculture by farming in integrated recirculating systems in asia: Zafira. World Aquaculture 2002, Beijing, World Aquaculture Society, USA.

Schneider, O., Sereti, V., Eding, E.H., Verreth, J.A.J., 2005. Analysis of nutrient flows in integrated intensive aquaculture systems. Aquacult. Eng. 32, 379-401. 
Schneider, O., Blancheton, J. P., Varadi, L., Eding, E. H., Verreth, J. A. J., 2006. Cost price and production strategies in european recirculation systems. Linking Tradition \& Technology Highest Quality for the Consumer, Firenze, Italy, WAS.

Schneider, O., Schram, E., Poelman, M., Rothuis, A., van Duijn, A., van der Mheen, H., 2010. Practices in managing finfish aquaculture using ras technologies, the dutch example. OECD workshop on Advancing the Aquaculture Agenda, Paris, France, OECD.

Schram, E., Person-Le Ruyet, J., Blancheton, J. P., Vinçon, B., Verniau, B., Jansen, J., Schneider, O., 2009. Long-term effects of water refreshment rate on turbot growth. "new research frontiers", novel approaches for evolving needs, Trondheim, Norway, EAS.

Suantika, G., Dhert, P., Rombaut, G., Vandenberghe, J., De Wolf, T., Sorgeloos, P., 2001. The use of ozone in a high density recirculation system for rotifers. Aquaculture 201, 35-49.

Summerfelt, S. T., Adler, P. R., Glenn, D. M., Kretschmann, R. N., 1999. Aquaculture sludge removal and stabilization within created wetlands. Aquacult. Eng. 19, 81-92.

Summerfelt, S.T., 2003. Ozonation and UV irradiation - An introduction and examples of current applications. Aquacultural Engineering 28, 21-36.

Summerfelt, S. T., Davidson, J. W., Waldrop, T. B., Tsukuda, S. M., Bebak-Williams, J., 2004. A partial-reuse system for coldwater aquaculture. Aquacult. Eng. 31, 157-181.

Summerfelt, S.T., Sharrer, M.J., Tsukuda, S.M., Gearheart, M., 2009. Process requirements for achieving full-flow disinfection of recirculating water using ozonation and UV irradiation Aquacult. Eng. 40, 17-27.

Tal, Y., Watts, J.E.M., Schreier, H.J., 2006. Anaerobic ammonium-oxidizing (Anammox) bacteria and associated activity in fixed-film biofilters of a marine recirculating aquaculture system. Appl. Environ. Microbiol. 72, 2896-2904.

Tal, Y., Schreier, H.J., Sowers, K.R., Stubblefield, J.D., Place, A.R., Zohar, Y., 2009. Environmentally sustainable land-based marine aquaculture. Aquaculture 286, 28-35.

Tango, M.S., Gagnon, G.A., 2003. Impact of ozonation on water quality in marine recirculation systems. Aquacult. Eng. 29, 125-137.

Terjesen, B. F., Ulgenes, Y., Færa, S. O., Summerfelt, S. T., Brunsvik, P., Baeverfjord, G., Nerland, S., Takle, H., Norvik, O. C., Kittelsen, A., 2008. RAS research facility dimensioning and design: a special case compared to planning production systems. In Aquaculture Engineering Society Issues Forum Proceedings. Roanoke, Virginia, 23rd-24th July, 223-238. van Duijn, A. P., Schneider, O., Poelman, M., van der Veen, H., Beukers, R., 2010. Visteelt in nederland: Analyse en aanzet tot actie. Den Haag, LEI: 56.

van Rijn, J., Tal, Y., Schreier, H. J., 2006. Denitrification in recirculating systems: Theory and applications. Aquacult. Eng. 34, 364-376

Verdegem, M. C. J., Eding, E. H., van Rooy, J. M., Verreth, J. A. J., 1999. Comparison of Effluents from Pond and Recirculating Production Systems receiving Formulated Diets. World Aquac. 30, 28-32.

Verdegem, M. C. J., Bosma, R. H., Verreth, J. A. J., 2006. Reducing water use for animal production through aquaculture. Int. J. Water Resour. Dev. 22, 101-113.

Verdegem, M. C. J., Bosma, R. H., 2009. Water withdrawal for brackish and inland aquaculture, and options to produce more fish in ponds with present water use. Water Policy $11,52-68$.

Verreth, J. A. J., Eding, E. H., 1993. European Farming Industry of African Catfish (Clarias gariepinus) Facts and Figures. J. World Aquacult. Soc. 24, 6-13.

Vymazal, J., 2009. The use constructed wetlands with horizontal sub-surface flow for various types of wastewater. Ecol. Eng. 35, 1-17.

Wang, J. K., 2003. Conceptual design of a microalgae-based recirculating oyster and shrimp system. Aquacult. Eng. 28, 37-46.

Wolters, W., Masters, A., Vinci, B., Summerfelt, S., 2009. Design, loading, and water quality in recirculating systems for Atlantic Salmon (Salmo salar) at the USDA ARS National Cold Water Marine Aquaculture Center (Franklin, Maine). Aquacult. Eng.41, 60-70

Yilmaz, G., Lemaire, R., Keller, J., Yuan, Z., 2008. Simultaneous nitrification, denitrification, and phosphorus removal from nutrient-rich industrial wastewater using granular sludge. Biotechnol. Bioeng. 100, 529-541. 
Zohar, Y., Tal, Y., Schreier, H. J., Steven, C., Stubblefield, J. and Place., A., 2005. Commercially feasible urban recirculated aquaculture: Addressing the marine sector. In, Urban Aquaculture, B. Costa-Pierce, ed. CABI Publishing, Cambridge, MA, pp. 159-171 
Table 1. Grow-out production (metric tones/year) in RAS from 1986 until 2009. Data were obtained by interviews with relevant stakeholders (feed industry, farmers, associations etc) in the different European countries.

\begin{tabular}{|c|c|c|c|c|c|c|c|c|c|c|}
\hline & 1986 & 1990 & 2002 & 2003 & 2004 & 2005 & 2006 & 2007 & 2008 & 2009 \\
\hline Belgium & & & & & & 10 & & & & \\
\hline Bulgaria & & & & & & 5 & & & & 20 \\
\hline Czech & & & & & & & & & & 235 \\
\hline \multicolumn{11}{|l|}{ Republic } \\
\hline Denmark & & & & & & 2000 & & & & 12000 \\
\hline Estonia & & & & & & & & & 40 & \\
\hline Finland & & & & & & 130 & & & & \\
\hline France & & & & & & 70 & & & & 506 \\
\hline Germany & & & 502 & 509 & 688 & 657 & & 1257 & & \\
\hline Hungary & & & & & & 650 & & & & 24.5 \\
\hline Ireland & & & & & & & & & & 50 \\
\hline Lithuania & & & & & & & & 15 & & \\
\hline Netherlands & 300 & 950 & & & & 9500 & & 9635 & & 9680 \\
\hline Poland & & & & & & 180 & & & & \\
\hline Portugal & & & & & & & & 100 & 110 & 112 \\
\hline Spain & & & & & & 580 & & & & 780 \\
\hline Sweden & & & & & & 490 & & & & \\
\hline United & & & & & & & & & & 100 \\
\hline Kingdom & & & & & & & & & & \\
\hline
\end{tabular}


Table 2. Comparison of fingerling production (fingerling heads/year) in RAS between 2005 and 2009. Data were obtained by interviews with relevant stakeholders (feed industry, farmers, associations etc) in the different European countries.

\begin{tabular}{lcc}
\hline & 2005 & 2009 \\
\hline Bosnia & and & 260000 \\
Herzegovina & & \\
Bulgaria & & 5000000 \\
Czech Republic & & 60000000 \\
Faroe Islands & 4000000 & 6500000 \\
France & 61400000 & 73729000 \\
Hungary & 650000 & 367500 \\
Italy & 90000000 & \\
Norway & 350000 & 3800000 \\
Portugal & 10000000 & \\
Shetlands & 500000 & \\
Spain & 5000000 & \\
United Kingdom & 2500000 & 1550000 \\
\hline
\end{tabular}


Table 3. Energy consumption by various fish production systems (fisheries and aquaculture). Species

$\begin{array}{cccc}\text { Production } & \text { Feed } & \text { Functioning } & \text { Total } \\ \text { tool }^{*}\left(\mathrm{kWh}^{*} \mathrm{~kg}^{-}\right. & \left(\mathrm{kWh}^{*} \mathrm{~kg}^{-1}\right) & * *\left(\mathrm{kWh}^{*} \mathrm{~kg}^{-1}\right) & \left(\mathrm{kWh}^{*} \mathrm{~kg}^{-1}\right)\end{array}$

\begin{tabular}{llcccc} 
& \multicolumn{1}{c}{${ }^{1}$ ) } & & & \\
\hline Fisheries & Hering (1) & 0.25 & 0 & 1 & 1.25 \\
& Cod (1) & $1-5$ & 0 & $4-16$ & $5-21$ \\
& Lobster (1) & $10-22$ & 0 & $40-90$ & $50-112$ \\
Aquaculture & Mussel (2) & & 0 & & 0.7 \\
& Trout, FTS (3,4) & 3 & $5-6$ & $1-2$ & $10-12$ \\
& Trout or bass RAS (4) & $6-7$ & $5-6$ & $3-6$ & $15-20$ \\
& Large trout FTS (4,5) & & & & 22 \\
& Oyster (6) & & & & 26
\end{tabular}

$\begin{array}{lll}\text { Tilapia conventional RAS } & \mathbf{5 . 2}\end{array}$

(7)

Tilapia denitrification RAS

2.2

(7)

1) Ziegler et al., 2006, (2) Thrane, 2006, (3) Papatryphon et al., 2004a,b (4) Roque d'Orbcastel et al., 2009c, (5) Aubin et al., 2009 , (6) Pimentel et al, 1996, (7) Eding et al., 2009; * means energy to build the system; ${ }^{* *}$ means energy needed to operate the system 
Table 4. Comparison of environmental sustainability indicators for a hypothetical $100 \mathrm{MT} / \mathrm{y}$ intensive tilapia farm with conventional RAS and RAS using a denitrification reactor (Eding et al., 2009).

\begin{tabular}{|c|c|c|}
\hline & Conventional RAS & Denitrification RAS \\
\hline \multicolumn{3}{|l|}{ Resource use } \\
\hline Fingerlings (\#/kg) & 1.2 & 1.2 \\
\hline Feed $(\mathrm{kg} / \mathrm{kg})$ & 1.22 & 1.22 \\
\hline Electricity (kWh/kg) & 1.8 & 2.2 \\
\hline Heating $(\mathrm{kWh} / \mathrm{kg})$ & 3.4 & 0.0 \\
\hline Water (L/kg) & 238 & 38 \\
\hline Oxygen $(\mathrm{kg} / \mathrm{kg})$ & 1.18 & 1.26 \\
\hline Bicarbonate (g/kg) & 252 & $107^{\mathrm{a}}$ \\
\hline Labour (h/MT) & 12.5 & 13.1 \\
\hline \multicolumn{3}{|l|}{ Nutrient utilization } \\
\hline Nitrogen (\% of input) & 32 & 32 \\
\hline Phorphorus (\% of input) & 43 & 43 \\
\hline COD (\% of input) & 32 & 32 \\
\hline TOD (\% of input) & 32 & 32 \\
\hline \multicolumn{3}{|l|}{ Waste discharge } \\
\hline \multicolumn{3}{|l|}{ Nitrogen } \\
\hline Solid (g/kg) & 8.5 & 2.6 \\
\hline Dissolved ( $\mathrm{g} / \mathrm{kg})$ & 37.4 & 5.9 \\
\hline \multicolumn{3}{|l|}{ Phosphorus } \\
\hline Solid (g/kg) & 4.5 & 7.2 \\
\hline Dissolved (g/kg) & 3.8 & 1.3 \\
\hline \multicolumn{3}{|l|}{ COD } \\
\hline Solid (g/kg) & 189 & 84 \\
\hline Dissolved (g/kg) & 40 & 9 \\
\hline \multicolumn{3}{|l|}{ TOD } \\
\hline Solid (g/kg) & 227 & 95 \\
\hline Dissolved (g/kg) & 48 & 11 \\
\hline $\mathrm{CO}_{2}(\mathrm{~kg} / \mathrm{kg}$ incl gas $)$ & 1.58 & 1.10 \\
\hline TDS $(\mathrm{g} / \mathrm{kg})$ & 62 & 28 \\
\hline Conductivity $(\mu \mathrm{S} / \mathrm{cm})$ & 1060 & 2000 \\
\hline
\end{tabular}




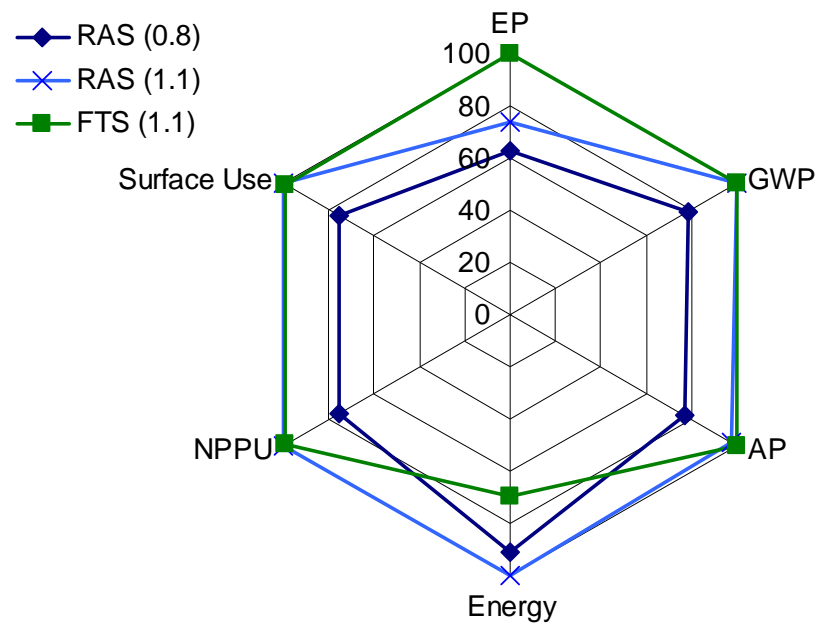

Figure 1. Comparison of the environmental impact of three scenarios of trout production systems (average production of 500 tons per year): 1) traditional flow through farm (FTS) , 2) hypothetic farm in RAS (with FCR of 1.1) and 3) RAS (with FCR of 0.8 ). RAS data were extrapolated from 2 years of experimental data obtained on pilot Danish model farms (Roque d'Orbcastel, 2008); environmental impacts are represented in proportion of the largest impact (\%). 


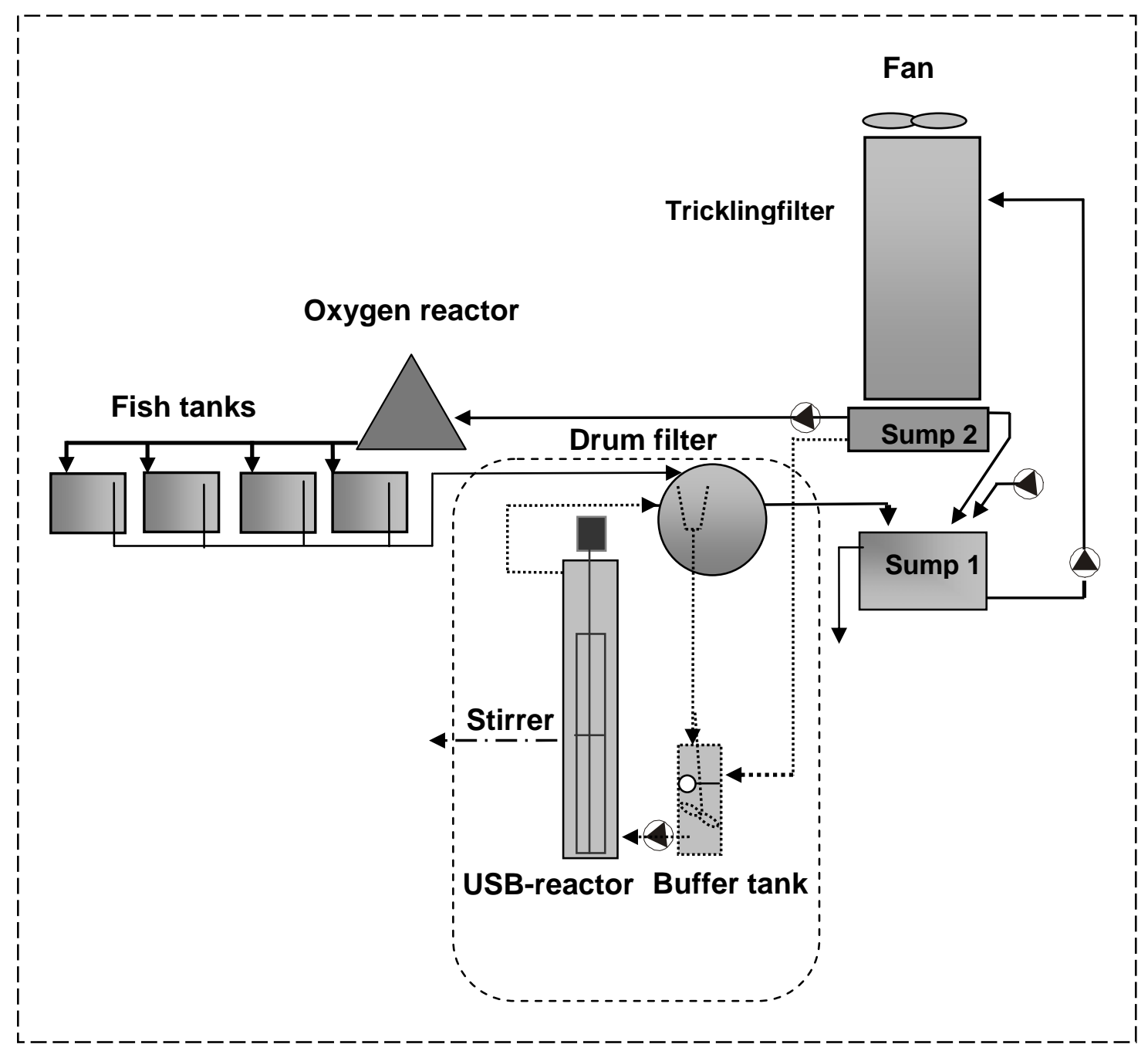

Figure 2. Innovative RAS using a denitrification (USB) reactor. Water flows from rearing tanks- drum filter - sump 1- trickling filter- sump 2-rearing tanks. One parallel flow across the denitrification reactor, using only fecal carbon as energy source, flows from the drum filter - buffer tank- denitrifying reactor-drum filter. 